\title{
Management disclosure practices for disaggregated (financial) information in Slovenian unlisted companies
}

\author{
Daniel Zdolsek, Iztok Kolar ${ }^{* *}$
}

The focus of the present study is the management practice of disclosing disaggregated (financial) information in a company's annual report. In this study, a sample of 232 Slovenian unlisted companies has been examined. The results show that less than a quarter of the companies disclose disaggregated information. Moreover, the multiple regression analysis reveals that the scope of the disclosed disaggregated information is not influenced by the company's size, financial leverage, profitability or growth, but that only a company's membership in the construction industry sector is a relevant determinant. Furthermore, additional analysis reveals that the companies' proprietary information does not influence the management practices regarding which disaggregated information to disclose.

Die vorliegende Studie befasst sich mit Berichterstattungspraktiken des Managements in Bezug auf segmentierte (Finanz-)Daten im Jahresbericht slowenischer Unternehmen. In dieser Studie wurde eine Auswahl von 232 slowenischen nicht börsennotierten Unternehmen untersucht. Die Ergebnisse zeigen, dass segmentierte Informationen von weniger als einem Viertel der Unternehmen offengelegt werden. Darüber hinaus zeigt die multiple Regressionsanalyse, dass der Umfang der offengelegten segmentierten Daten nicht etwa durch die Unternehmensgröße, dem Verhältnis von Fremdkapital zu Eigenkapital (,Financial Leverage“), Rentabilität oder Wachstum des Unternehmens beeinflusst wird. Relevant ist die Tatsache, ob die Unternehmen in der Baubranche tätig sind. Darüber hinaus beeinflussen firmeneigene (proprietäre) Informationen die Berichterstattungspraktiken des Managements, insbesondere in Bezug auf die Auswahl der offenzulegenden segmentierten Daten, nicht.

Key words: studies, disaggregated (financial) information disclosures, management's choice of disclosure policy, management behavior, strategic management, Slovenia

\footnotetext{
Manuscript received: 15.7.11, accepted 23.10.12 (1 revision)

** Daniel Zdolsek, MSc, Research Assistant, University of Maribor, Faculty of Economics and Business, Department for Accounting and Auditing. Main research interests: financial reporting (accounting) and auditing issues. Corresponding address: daniel.zdolsek@uni-mb.si

Iztok Kolar, Assistant Professor, PhD, University of Maribor, Faculty of Economics and Business, Department for Accounting and Auditing. Main research interests: financial reporting (accounting), management accounting and auditing issues. Corresponding address: iztok.kolar@uni-mb.si
} 


\section{Introduction}

Whether to disclose information by segments is a dilemma for the management of a company (and also for the management of a group of companies). This decision is a dilemma because, from the point of view of the company, disclosing information by segments has various simultaneous economic consequences. When choosing to disclose information by segments, the potential (positive) advantages for the company are shown in the form of a lower requested rate of return on capital, lower financing costs, an improvement of the credit status, the growth of the company's management reputation, increased transparency of information about the company and other similar beneficial consequences (see, i.e., Botosan 2000; Behn et al. 2002; Berger/Hann 2003; Piotroski 2003; Botosan/Stanford 2005; Francis et al. 2005; Paul/Largay III 2005; etc.). The undesirable consequences of segment disclosures could be in the form of the company's eroded advantage vis-à-vis its competitors, an increase in the competition costs followed by a fall in the above-average earnings by segments, the possibility of managements' replacement or a change in managements' remuneration and other negative results (see, i.e., Hayes/Lundholm 1996; Harris 1998; Sanders et al. 1999; Deppe/Omer 2000; Berger/Hann 2003, 2007; etc.). Nevertheless, segment disclosures (as part of financial statements and their disclosures) provide their users with an alternative performance indicator for the company's success. These disclosures can reveal detailed information on the success of the company's various segments. The uncertainty of the company's management and their fear the company's burdens could increase if (too much) proprietary information is disclosed by segments can lead to a decrease in managements' willingness to disclose the segment information.

Accounting standards (as pronouncements) are a framework within which the management in listed and unlisted companies operate. The standards that require disclosures create the basic framework of a wide information environment for the users of financial statements (i.e., present and potential investors and lenders, financial analysts, suppliers, employees, customers, governments, the local community, parties performing a review or oversight function, and/or the media). When disclosing segment information, the management can independently decide on the accounting policy of the company if this action is permitted by the generally accepted accounting principles. The decision regarding the disclosure of information, including proprietary information, is a strategic management decision, and the consequence (beneficial or nonbeneficial) of the individual segment information disclosure is (generally) not known in advance.

Due to the possible aforementioned negative consequences from disclosing information by segments, it can be expected that the management of companies 
will not completely disclose this information. Companies often disclose only some information by segments (Healy/Palepu 2001), even though they could disclose more information that is available within the company and is not regarded as proprietary. However, it is worth mentioning that the ability of management to exercise discretionary decision making (i.e., not to disclose any segment information) has decreased from when the first standards were introduced (at the end of the 1960s) until today due to the dynamic development of financial reporting standards and other pronouncements that regulate segment disclosures. The first accounting standards that required the disclosure of segment information (such as the SFAS 14 and the IAS 14) ${ }^{1}$ allowed a great degree of subjective decision making from the companies' management regarding what to disclose, to what extent and how. The subsequent accounting standards (SFAS 131, renamed ASC 280 in 2009, and IFRS 8) ${ }^{2}$ significantly limited the possibility of discretionary decision making from the management of listed and unlisted companies during that time period. As the results of the various studies based on a sample of listed companies show (Ettredge et al. 2000; Herrmann/Thomas 2000; Street et al. 2000; Berger/Hann 2003, 2007; Botosan/Stanford 2005; Paul/Largay III 2005; Birt et al. 2007), the number of disclosed segments compared to the previous periods has significantly increased, the consistency of segment reporting is better and, most importantly, the extent of the information on segments is greater.

Irrespective of the requirements of various pronouncements, the management of listed or unlisted companies is independent (autonomous) when taking the (strategic) decision to disclose (or conceal) any type of information (proprietary or non-proprietary) about the company in the annual report. Management disclosures of information by segments are regarded as disclosures of proprietary information. Because of the various possible negative consequences for the company and for management (i.e., eroded advantage vis-à-vis competitors, an increase in the competition costs, the possibility of managements' replacement, etc.) from segment information disclosure, a company's management has an incentive to not disclose information by segments if it considers that the information by segments would result in undesired consequences for the company. Nevertheless, the results of the aforementioned studies reveal that the management of listed companies usually does disclose information by segments. However, the actual behaviour ("business practise") of the management of unlisted companies in relation to the disclosure of information by segments is unknown. ${ }^{3}$ The management of an

SFAS 14 - Financial Reporting for Segments of a Business Enterprise (1976) and IAS 14 - Reporting Financial Information by Segment (1981).

2 SFAS 131 - Disclosures about Segments of an Enterprise and Related Information (1997; from 2009 onwards ASC 280 - Segment Reporting) and IFRS 8 - Operating Segments (2006).

3 Management behaviour at unlisted companies has previously not been studied. We are not aware of the existence of any other (publicly available) study that is based on a sample of unlisted companies. 
unlisted company will weigh the possible economic consequences of the disclosure of (proprietary) segment information when choosing whether to disclose information by segments. Nevertheless, the management at companies in the countries in transition, such as Slovenia ${ }^{4}$, frequently adopt key initiatives in the development of a company and its policy (Mühlbacher et al. 2011), and the results of one study show that the observance of legal and technical pronouncements is important to the management at companies in Slovenia (Mihelič/Lipičnik 2010). Knowing these earlier study findings, this study examines the management behaviour ("business practise") in unlisted Slovenian companies in relation to disclosures by segments, which are mandatory disclosures in accordance with pronouncements. Additionally, the possible determinants of the disclosure of segment information by unlisted companies are studied.

The remainder of the paper is organised as follows. In the first two chapters, there is an overview of the Slovenian corporate reporting environment and a brief review of the previous research. The methodological overview, the sample data, the sampling procedure, the variables and the regression model are presented in chapter four. An analysis of our results is provided in chapter five, including a discussion of results. Chapter six of this paper summarises our key findings.

\section{Pronouncements about disclosing disaggregated information in Slovenia}

In Slovenia, there are no legal pronouncements that require companies to thoroughly and comprehensively disclose segment information. Subject to legal pronouncements and in accordance with the Companies Act $(\mathrm{CA})^{5}$ and its further amendments, Slovenian companies were not obliged to disclose any type of information by segments prior to 23 June 2001. After this date, an amended $\mathrm{CA}$ went into force that was harmonised with the European Union (EU) company law $^{6}$ (now the CA-1 and its further amendments), according to which the companies were required to disclose at least some information by segments, as follows. Companies are now required to disclose the net turnover for "areas of activity" and the net turnover for "geographical markets" in the notes to the

\footnotetext{
4 Slovenia is one of the countries in (or near the end of) transition in Eastern Europe; it is a former state of Yugoslavia, which was disintegrated between the early 1990s and into the $21^{\text {st }}$ century, and it has been a member of the EU since 2004. For more on the economic and other characteristics of Slovenia as a country, see Čater and Pučko (2010: 209, footnote 1), and of Slovenia as a population, see Mihelič and Lipičnik (2010: 293 onwards).

5 The Companies Act (CA) was published in the Official Gazette of the RS, n. 30/1993 of 10 June 1993.

6 The CA was harmonised with the following EU directives: Fourth Council Directive (of 25 July 1978) on the annual accounts of certain types of companies (78/660/EEC) and Seventh Council Directive (of 13 June 1983) on consolidated accounts (83/349/EEC). In the following years, both directives were amended and changed many times. In 2006, the existing CA was superseded with the new Companies Act (CA-1), published in the Official Gazette of the RS, n. 42/2006 of 19 April 2006.
} 
financial statements; however, this requirement is in force only when these net turnovers in the areas of activity and geographical markets differ significantly from one another. In relation to this requirement, the legal pronouncements do not state any detailed instructions nor do they provide a more specific explanation, such as what is (what is represented by) "the category of activity", what is (what is represented by) the "geographical market" and how (in what way) this information should be disclosed.

Accounting standards are pronouncements according to which (under CA-1) the companies must prepare financial statements and disclosures (of accounting information). Until 2005, the companies in Slovenia were obliged to use the then valid Slovene accounting standards (SAS), whereas since 2005, the companies in Slovenia are obliged to use the SAS or the International Financial Reporting Standards (IFRS), which are endorsed by the EU, when preparing their financial statements. The companies that use the IFRS ${ }^{7}$ therefore used the IAS $14 \mathrm{R}^{8}$ through 2008, whereas from 1 January 2009, the use of IFRS 8, which changed the previously valid approach to segment reporting in the IAS 14R, is obligatory.

The SAS, which were valid from 28 December 2005 onwards, describe in more detail the preparation and disclosure of information by segments in its various standards. Many new solutions related to segment reporting were included in the SAS, which are the same as the solutions from the IAS 14R that was valid in that period. Contrary to legal pronouncements, the operational definitions of the business segment and the geographical segment are included in the SAS. The segment reporting disclosure pronouncements under SAS are listed in Table 1.

Table 1: SAS segment reporting pronouncements

\begin{tabular}{|c|l|c|}
\hline & Disclosure of ... & $\begin{array}{c}\text { Pronouncement } \\
\text { under SAS }^{\dagger}\end{array}$ \\
\hline 1 & $\ldots$ business segment composition & 25.27 \\
\hline 2 & $\ldots$ geographical segment composition & 25.27 \\
\hline 3 & $\ldots$ profit or loss results by segment & 19.23 \\
\hline 4 & $\ldots$ revenues by segment & 25.35 \\
\hline 5 & $\ldots$ revenues by segment in table form & \\
\hline
\end{tabular}

7 In accordance with the CA-1, the IFRS, endorsed by the EU, should be used by the following when preparing financial statements: 1) unlisted companies in the EU Member States that are obliged to prepare a consolidated annual report, 2) banks, 3) insurance companies and 4) other companies, if so decided at a general meeting of a company, however, the IFRS should be used when preparing financial statements at least for a period of five years (see CA-1, 54/10 and 54/11). All other companies can use the SAS, which are valid in Slovenia.

8 IAS $14 \mathrm{R}$ is the abbreviation for IAS 14 (Revised) - Segment Reporting (1997). 


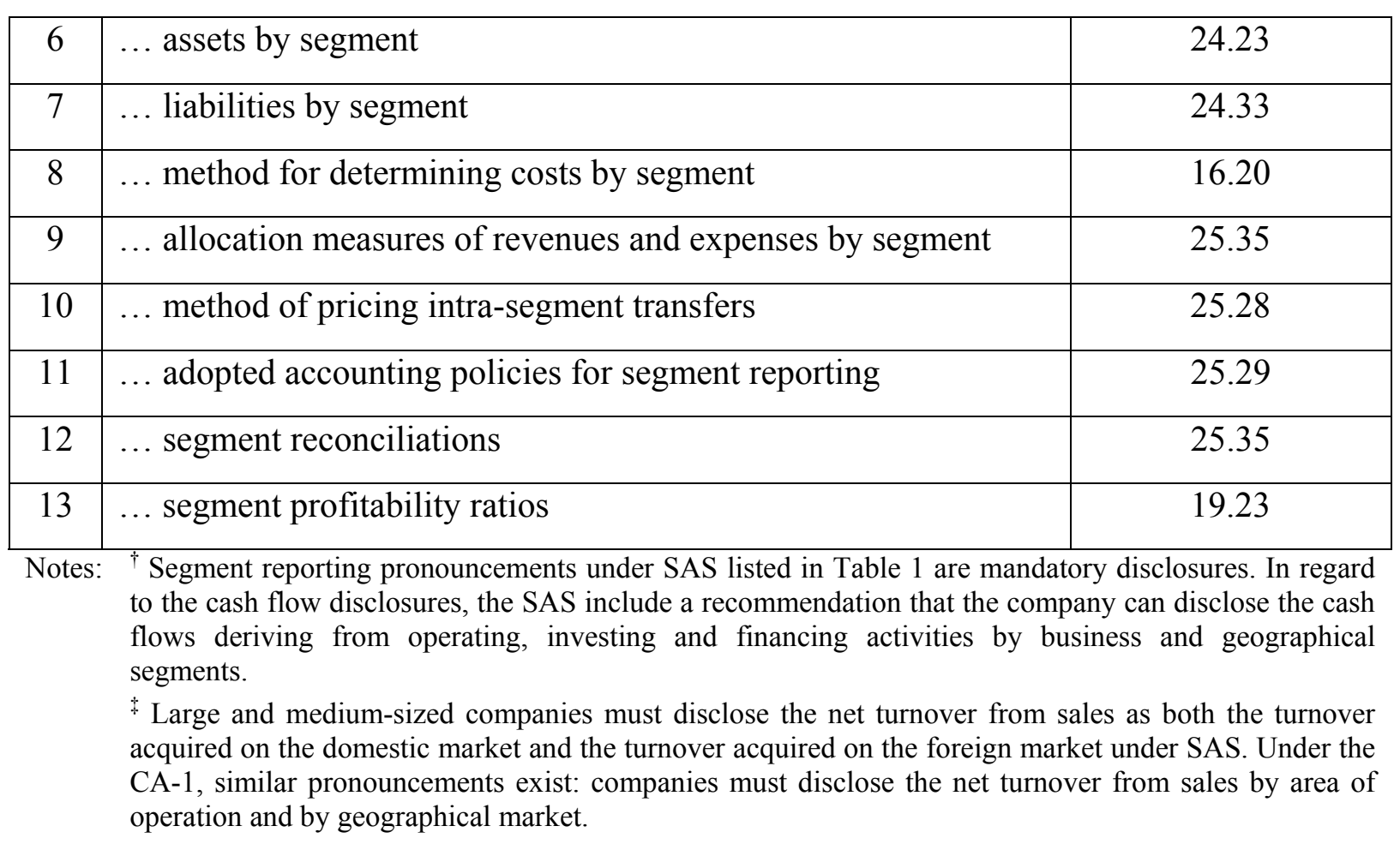

\section{Research background and hypothesis development}

Accounting standards are a framework, within which the company management operates. The researchers of the segment information disclosures, such as Harris (1998), Herrmann and Thomas (2000), Doupnik and Seese (2001), Behn et al. (2002), Street and Nichols (2002), Ettredge et al. (2002, 2005, 2006), Berger and Hann (2003, 2007), Prather-Kinsley and Meek (2004), Prencipe (2004), Botosan and Stanford (2005) and many others, therefore, try to discover the attitude of the company's management towards the disclosure of segment information (for example, whether a company should disclose the achievements of its segments, should it disclose the liabilities attributed to each segment, etc.). In several of these studies, the company's management usually discloses the (mandatory) segment information but are reluctant (opposed) to disclose further segment information. Other studies explore the question of why some companies disclose more (or less) segment information than others. There are companies whose management did disclose more segment information in the presence of intense company competition, in the absence of proprietary information, etc.

If company is seen as a nexus of contracts between different individuals and groups, it could be argued that varied information (i.e., segment information) is used as the basis to establish contracts and to control these contracts (Jensen/Meckling 1976). The contracts specify the performance evaluation metrics of the company's agents and their remuneration system. Information asymmetries across the various investors (as principals) and between managers (as agents) and principals lead to the disclosure of company information. 
The study results (Maines et al. 1997; Deppe/Omer 2000; Behn et al. 2002; Berger/Hann 2003; Ettredge et al. 2005; Troberg et al. 2010) indicate that the disclosed segment information has an important influence on the market (for example, for financial analysts, see Botosan/Stanford (2005) and Troberg et al. (2010) for various quoted references). In addition, more research (Hayes/Lundholm 1996; Harris 1998; Botosan/Stanford 2005; Berger/Hann 2007) shows that the disclosures of segment information are not complete. One mechanism for explaining behaviour regarding the information policy disclosure followed by companies is signalling (Spence 1973). A company's segment information can indicate the company's underlying reality and the segment information can influence the external users when they are making decisions regarding the company.

However, managements' reluctance to disclose segment information indicates the potential presence of a motive to conceal segment information due to one or more proprietary costs. The earlier studies about the disclosure of segment information (Hayes/Lundholm 1996; Harris 1998; Ettredge et al. 2002; Piotroski 2003; Prencipe 2004; Botosan/Stanford 2005; Berger/Hann 2007) show that the management at different companies has different approaches to recognising the possible discretionary decisions about the disclosure of information by segments due to the potential existence of proprietary costs. ${ }^{9}$ Company management will therefore be less likely to disclose segment information, which could enable or has been enabling above-average profits over the long term (Harris 1998). This factor influences the decision-making of the company's management regarding the definition of segments. Due to the concealment of this type and other types of similar information, the company's management chooses the highest level of information aggregation for the segment disclosures (Hayes/Lundholm 1996; Berger/Hann 2007). Large companies that have more competition and operate in a number of different segments try to conceal information about their profitable activities by disclosing only one segment (Hayes/Lundholm 1996; Troberg et al. 2010). ${ }^{10}$ It is also a fact that management will always try to conceal information about the segments that are going to or that have been achieving below-average profits (Berger/Hann 2007).

\footnotetext{
9 Decisions and accounting policies, including the disclosure of information, are (often) interdependent (Mian/Smith 1990; Christie/Zimmerman 1994). It is also true that many factors can influence a particular type of disclosure from the company's management (Meek et al. 1995). On the hypothesis of the rational behaviour of the company's management, it holds true that management will reveal information when the extent of the (potential) benefits for management is higher than the extent of the (potential) costs for management. If the consequences for the company's management are unfavourable, management will not disclose information regardless of the potential costs related to management control and to management sanctioning and regardless of the accepted accounting policy related to the disclosure of information (including the disclosure of information by segments). In addition, if the consequences for the company's management are favourable, the company will disclose information, ceteris paribus.

10 Nevertheless, considering the results of the study performed by Mihelič and Lipičnik (2010), it is worth adding that honesty is ranked as one of the three most important values in Slovenia, a viewpoint that is comparable to the viewpoints of managers from other countries.
} 
According to the concise framework provided above, a few hypotheses have been developed to explain a company's segment disclosure policy.

Company size. Larger companies are expected to disclose more information by segments than smaller companies. If a company is externally financed, there are possible conflicts among managers, creditors and investors. The disclosure of information (i.e., segment information) is used to decrease agency costs and to reduce information asymmetries between the company and the (actual and potential) providers of company funds. Nevertheless, the larger the company is, the smaller the proprietary costs. The company size was a significant factor for information disclosure in various countries in a number of former studies (i.e., McKinnon/Dalimunthe 1993; Herrmann/Thomas 1996; Leuz 2004; Prencipe 2004; Barako 2007; and many others).

Financial leverage. The companies with high financial leverage are expected to disclose more information by segments than the companies with low financial leverage. If a company is highly leveraged, there are possible conflicts in the relationship between managers and investors. The disclosed information (i.e., segment information) can be used to avoid (decrease) agency costs and reduce information asymmetries. Financial leverage was a significant factor for information disclosure in several former studies (i.e., Mitchell et al. 1995; Prencipe 2004; Barako 2007), but nonetheless was not a significant factor in other studies (i.e., Chow/Wong-Boren 1987; McKinnon/Dalimunthe 1993; Leuz 2004).

Profitability. The companies with higher profitability are expected to disclose more information by segment than the companies with lower profitability. The managers of profitable companies will disclose various information (i.e., segment information) to obtain their personal perks. However, the managers of non-profitable companies will disclose less information. Signals to the market and other external users regarding below average profitability for a company would be unwanted by the company's managers. Furthermore, substantial companies with greater profitability are expected to disclose less information by segments than companies with lower profitability. Profitability was not found in other studies to be a significant factor for information disclosure (i.e., Harris 1998; Piotroski 2003; Leuz 2004), but it has nonetheless been considered in this study (because it was statistically significant in some studies, i.e., Wallace/Naser 1995; Prencipe 2004).

Company growth. The greater the company's growth, the smaller the extent of information by segment that a company discloses. The disclosure of information by segment can have one or many (actual or potential) undesired harmful 
consequences for the company, ${ }^{11}$ especially if the competition and/or other customers exploit any detected weaknesses and/or opportunities based on the disclosed information. An aggravated competitive environment can lead to problems related to the company's growth. ${ }^{12}$ The growth of the company is, in fact, often connected to the entrance into one or many (profitable) markets or/and to the existence of one or many expanding markets. ${ }^{13}$ For a company that devotes its available resources to operating in these markets - thus for the company's growth - the emergence of (potential) proprietary costs represents a bigger burden than they do to a company that does not devote its available resources to the activities in these markets (Prencipe 2004). The disclosure of information, including the segment information disclosure, to the competition and other people can decrease the potential economic benefits of the disclosing company (and, at the same time, increases proprietary costs). A growing company will therefore be likely to disclose less information. Company growth has not been considered to be a significant information disclosure factor in any other study, but it has nonetheless been considered in this study.

Company's industry sector. Companies in the same industry sector will disclose similar information to various external users. A company's information disclosure policy might be a way to follow other companies in the same industry sector. The existence of a company with an information disclosure policy that is substantially different from the information disclosure policies of other companies in the same industry sector could be interpreted by the market and other external users as unwanted news by the company. The industry sector was not a significant factor for information disclosure in other studies (i.e., Wallace et al. 1994; Barako 2007) but, nonetheless, was a significant factor in some of the studies (i.e., McKinnon/Dalimunthe 1993; Mitchell et al. 1995).

\section{Research design}

\section{Overview of the research methodology}

When researching the area of information disclosure, a "point system" is commonly used to measure the disclosure of (accounting) information (that is, disclosure items) in the companies' annual reports (Chavent et al. 2006; Hossain/Hammami 2009; Urquiza et al. 2010). Thus, it generally holds true that

11 The undesired consequences of segment disclosures could be in the form of an eroded company advantage vis-à-vis competitors, an increase in competition costs followed by a fall in the above-average earnings by segments, the possibility of managements' replacement or a change in managements' remuneration and other negative consequences (see, i.e., Hayes/Lundholm 1996; Harris 1998; Sanders et al. 1999; Deppe/Omer 2000; Berger/Hann 2003, 2007; etc.).

12 It is anticipated that the segment information disclosures of a(n) (unlisted) company are influenced by the company's growth and not vice versa.

13 According to the findings of Mühlbacher et al. (2011), Slovenian managers have a positive attitude towards growth as well as towards innovation, market changes, restructuring, the emergence of new products or services and so on. 
in the dichotomous procedure, a disclosure item is attributed the value of one if it is disclosed; if it is not disclosed, however, it is attributed the value of zero. Based on the "evaluated disclosure items", it is possible to construct a disclosure index, which is the ratio between the actual extent of disclosure and the entire possible extent of all disclosures. An unweighted disclosure index is independent from the expectations of the individual users (Chow/Wong-Boren 1987). In many earlier studies, the unweighted disclosure index, and not the weighted disclosure index, was used because of this independence (Wallace et al. 1994; see Chavent et al. (2006) and Barako (2007) for various quoted references). To maintain impartiality (decrease the subjectivity as much as possible) and because of the problems related to the determination of different levels of importance for the disclosure items (their weights), it is advisable to use an unweighted disclosure index (Ahmed/Courtis 1999). Because all of the segment disclosures presented in Table 1 are mandatory segment disclosers under SAS, there does not exist a metric (information) that would enable the unequal weighting of these segment disclosures (as disclosure items). Therefore, when calculating the disclosure index, each disclosure item that is included in the disclosure index is attributed equal importance.

The disclosure index combines thirteen different disclosure items (segment disclosures presented in Table 1) and shows the extent of the company's information disclosure (as a measure of the extent of the company's disclosures). However, multiple regressions where the disclosure index represents a dependent variable do not indicate whether an individual disclosure item influences the disclosure of other items from the index or if there is possibly a pattern that is reflected in the behaviour of a company's management when disclosing information. The management of a company, in fact, acts in such a way that it discloses some types of information, while a management of any other company can disclose this same information, only a part of this information, other types of information or no information at all. Because of this problem, according to Chavent (1998), all disclosed information from companies must be studied using the divisive clustering method (DIV), which simultaneously determines the clustering tree structure for the classification of companies into clusters and provides a monothetic definition for each of the groups in the clustering tree structure. The cluster method is a method where the starting group is split in each subsequent step into two or more (monothetic and as homogeneous as possible) clusters $^{14}$, which are - considering the data comprised in the starting group - as different as possible (Chavent et al. 2006). In each step, the "splitting" is performed on the basis of one of the selected

\footnotetext{
14 A group is monothetic when the characteristics related to the group make an individual characteristic essential to enable the classification of the company into the group and when this characteristic is sufficient to classify the company into the group (Chavent et al. 2006: 194).
} 
variables and on the basis of the value of the selected variable (Chavent et al. 2006).

\section{Sample data}

The research is based on the examination of the disclosures in the 2009 annual reports of companies, published in 2010, that have their headquarters in Slovenia and can be defined as large ${ }^{15}$. It is reasonable to expect from the selected group of companies, which are large, non-group reporting subjects (or independent legal entities), that they have sufficiently extensive activities so that their segments will be determined and they will be more likely to disclose segment information than the medium-sized, small and micro companies. Additionally, in accordance with Article 57 of the CA-1, large companies must provide audited annual reports and the auditor must check the disclosed segment information in accordance with the International Standards on Auditing.

The data related to the disclosure of different segment information were hand collected (by the authors) from the annual reports of the examined companies. According to the criteria from Paragraph 5, Article 55 of the CA-1, there were 255 large companies in Slovenia on 31 December 2009. Out of the 255 companies, two companies had special legal organisational forms (cooperative and branch of a foreign company) ${ }^{16}$, one did not have an annual report at disposal (making it impossible to hand-collect the data related to the disclosure of information), and 20 companies had securities placed in different securities markets. Therefore, in total, there is a sample of 232 large unlisted companies. The results of the hand-collected data from the annual reports in this sample of 232 examined unlisted companies show that there are 50 companies that disclose information by segments in accordance with the pronouncements that are in force in Slovenia (SAS or IFRS). The remaining 182 large, unlisted companies do not disclose any information by segments in their annual reports as required by the pronouncements in force in Slovenia (out of these 182 companies, 19 use the IFRS, while 163 companies use the SAS).$^{17}$ Out of the 50 examined companies that disclose information by segments in their annual

15 In accordance with Article 55 of the CA-1, large companies fulfil at least two criteria out of the following: 1) they have over 250 employees, 2) they have over $€ 8.8$ million of net turnover from sales in the financial year and/or 3) they have assets of at least $€ 17.5$ million. The companies that are large according to other (qualitative) measures from Article 55 of the CA-1 (banks, insurance companies, etc.) but not according to the quantitative criteria defined by the CA-1 55/5 are not regarded as being large in this research. The data on the companies were acquired from the GVIN.com database.

16 Two special legal organisational forms, the cooperative and the branch of a foreign company, were excluded from the research because there are specific legal and accounting pronouncements that apply to them, and there is no sufficient guarantee that their disclosures are comparable to the disclosures of other ("regular") companies.

17 Finding that 182 out of 232 large unlisted companies do not disclose mandatory segment information in their annual reports as required by the pronouncements in force in Slovenia is unexpected. The reasons for the nondisclosure of segment information are not known. In general, it could be conjectured that the disclosure of segment information is not perceived to be beneficial by company management in Slovenia. 
reports, 9 use the IFRS, while 41 companies use the SAS. The 9 companies, who use the IFRS, were excluded from the sample of the 50 companies that disclose information by segments. The companies that use the IFRS were obliged to use IFRS 8 from 1 January 2009, which changed the previously valid approach of segment reporting in the IAS 14R with a "new" approach to reporting about segments. In the SAS, however, the approach to segment reporting has not been replaced with the "new" approach to segment reporting. A generalisation of the results regarding the companies that use the SAS would not be possible in this research because of the inclusion of these 9 companies, which use the IFRS. ${ }^{18}$

\section{Variables and regression model}

The disclosure index represents the aggregated measure of thirteen disclosure items (segment disclosures presented in Table 1). This research focuses on examining the companies that use the SAS, and there are no other available resources that address the behaviour of Slovenian company management in terms of the decision to disclose information by segments. Therefore, the source for determining the disclosure items for the disclosure index could only be represented by the requirements of the SAS related to the disclosure of segment information, which are mandatory disclosures.

The following were included in this research as possible variables that are related to the behaviour of company management when disclosing information by segments: the company size, the financial leverage, the profitability, the company's growth rate and the basic industry sector (as a dummy variable that shows the primary activity of the company). The variables in the research were measured as follows:

the natural logarithm of the value of the total (net) turnover (revenues) of the company was used as the measure for the company size (Herrmann/Thomas 1996; Prencipe 2004); ${ }^{19}$

the measure for the degree of financial leverage is presented as the ratio between the value of the total debts and the value of the company's total liabilities (capital and debt together) (Leuz 2004; Barako 2007);

18 Some basic (descriptive) statistical characteristics for the sample of the 41 large unlisted companies that disclose information by segments and use the SAS are the following (for the year 2009): the average value of assets is $€ 224$ million (an interval between $€ 21$ million and $€ 1,177$ million), the average value of financial and operating liabilities is $€ 88$ million (interval between $€ 5$ million and $€ 839$ million), the average net turnover from sales is $€ 147$ million (interval between $€ 16$ million and $€ 764$ million) and the average annual net profit is a little less than $€ 3$ million (interval between $€-44$ million and $€ 60$ million). The sample of the 41 large unlisted companies that disclose information by segments and use the SAS is not a large sample. Therefore, the chance that significant differences create a false positive is increased. Furthermore, in a small sample, the chance that important differences will be missed is increased. Therefore, regarding these study characteristics, there is an increased risk that the study results are inconclusive.

19 To avoid problems caused by heteroscedasticity, for example, the estimated parameters of a regression might not be efficient and the estimated variance might be biased, the natural logarithm of the variable is calculated (see Keene (1995) and Wooldridge (2002) for further discussion). 
the measure for profitability is the basic earning power coefficient, which is the ratio between earnings before interests and taxes (EBIT) and the average value of the company's assets (based on the company's data presented in 2008 and 2009); and

the growth rate of the company's assets, which is the ratio between the difference of the value of all assets in the current and the previous year and the value of all assets in the previous year (Prencipe 2004), is used as the measure of the company's growth rate.

Multiple regression was used in the research together with the ordinary least squares method, which was also used in a number of earlier studies related to the research on accounting information disclosure (see, i.e., Christie/Zimmerman 1994; Wallece/Naser 1995; Herrmann/Thomas 1996; Botosan 1997; Maines et al. 1997; Harris 1998; Prencipe 2004; Berger/Hann 2007; Hossain/Hammami 2009; Troberg et al. 2010). The regression model is provided with the regression function, which is

$$
\begin{aligned}
r_{i}= & \alpha+\beta_{1} \cdot[\text { Size_ln_Revenues }]+\beta_{2} \cdot[\text { Financial_leverage }]+\beta_{3} . \\
& {[\text { Profitability }]+} \\
& +\beta_{4} \cdot[\text { Growth_rate }]+\sum_{l=1}^{5} \beta_{5, l} \cdot[\text { Industry_dummy }]+\varepsilon_{i}
\end{aligned}
$$

where $r_{i}$ is the unweighted disclosure index, $\alpha$ is the regression constant, $\beta_{j}$ are the regression coefficients $(j=1,2,3,4,5)$ and $\varepsilon_{i}$ is an error term in the model. $^{20}$

\section{Findings and discussion}

To understand why one company's management discloses more (or less) information than another requires the examination of the information disclosure factors. The results of the regression analysis are presented in Table 2 . Considering the results of the multicollinearity analysis, the multicollinearity does not represent any major problems because the variance inflation factor does not exceed 10 (Chavent et al. 2006; O'Brien 2007; Hossain/Hammami 2009). A model with all included variables is statistically significant (at $F=2.577$, the $p$ value is lower than 0.05 ). The determination coefficient $\left(R^{2}\right)$ is 0.428 , whereas the adjusted determination coefficient (adjusted $R^{2}$ ) is 0.262. All of the variables, with the exception of the (dummy) variable that shows whether the company is classified in the construction sector, are statistically non-significant. The companies disclose a larger range of information by segments if they are

20 The dummy variable 'Industry_dummy' $(l=1,2,3,4,5)$ is an aggregate variable of other dummy variables related to the primary industry sector and takes the value of one if any of these dummy variables is valued at one (a company, thus, classified in the energy, construction, production, transport or commerce sectors), while it is valued at zero in all other cases. 
classified in the construction sector (the variable is statistically significant at 5 $\%)^{21}$

\section{Table 2: Multiple regression analysis results}

\begin{tabular}{|c|c|c|c|c|}
\hline \multirow[b]{2}{*}{ Panel A } & \multirow[t]{2}{*}{$\begin{array}{l}\text { Unstandardised } \\
\text { coefficients }\end{array}$} & \multicolumn{2}{|c|}{$\begin{array}{l}\text { Statistical } \\
\text { significance }\end{array}$} & \multirow[t]{2}{*}{$\begin{array}{l}\text { Variance } \\
\text { inflation } \\
\text { factor }\end{array}$} \\
\hline & & & & \\
\hline Size_ln_Revenues & .011 & .299 & & .767 \\
\hline Financial_leverage & -.152 & -.939 & & .355 \\
\hline Profitability & -.847 & -.631 & & .113 \\
\hline Growth_rate & -.092 & -.351 & & .728 \\
\hline Energy_industry_dummy & .044 & .316 & & .754 \\
\hline Construction_industry_dummy & .006 & .036 & ** & .971 \\
\hline Production_industry_dummy & -.213 & -.027 & & .051 \\
\hline Transport_industry_dummy & .057 & .448 & & .658 \\
\hline Commerce_industry_dummy & .022 & .159 & & .875 \\
\hline Constant & .299 & .459 & & .649 \\
\hline \multicolumn{5}{|l|}{ PANEL B } \\
\hline Dependent variable & \multicolumn{4}{|c|}{ Unweighted disclosure index } \\
\hline $\begin{array}{l}\text { Number of unlisted companies } \\
\text { included in studied sample }\end{array}$ & 41 & & & \\
\hline$F$ statistic & 2.577 & & & \\
\hline$p$-value & .024 & & & \\
\hline
\end{tabular}

21 Because there is some uncertainty regarding the form of the regression relationship, another analysis is performed with ranked variables of the model. The companies that had the same rank for the partial disclosures were attributed an average of the ranks that they would have had if they had not had the same ranks for the partial disclosures (Lang/Lundholm 1993). Even in this case, the model with ranked data is statistically significant (at $F=2.549$, the $p$-value is lower than 0.05 ). The determination coefficient $\left(R^{2}\right)$ is 0.425 , whereas the adjusted determination coefficient (adjusted $R^{2}$ ) is 0.258 . In the model with unranked data, all of the variables are statistically non-significant except two: the ranked variable of the company growth rate (at a $5 \%$ significance level) and the (dummy) variable that shows whether the company is classified in the construction sector (at a $10 \%$ significance level; results not shown here). The regression analysis was also performed in such a way that the (dummy) variable "Industry dummy" was not included in the regression model. With the "Industry_dummy" variable excluded from the model, the model is no longer statistically significant (in the sample of unranked data at $F=2.018$, the $p$-value is higher than 0.10 ; in the sample of ranked data at $F=1.961$ the $p$-value is higher than 0.10). Furthermore, the adjusted determination coefficient is 0.092 in the sample of unranked data and 0.088 in the sample of ranked data. The "Industry_dummy" variable is shown to be (statistically) significant in the behaviour of company management regarding the decision to disclose information by segments. 


\begin{tabular}{|l|l|l|l|l|}
\hline Determination coefficient $R^{2}$ & .428 & & & \\
\hline Adjusted determination coefficient $R^{2}$ & .262 & & & \\
\hline
\end{tabular}

Notes: * Statistically significant at $0.10 . * *$ Statistically significant at $0.05 . * * *$ Statistically significant at 0.01 .

The results of the regression analysis did not show any statistically significant factors that would influence the behaviour of company management in the disclosure of information by segments. Only if the company is classified in the construction sector (as the primary activity of the company) does the company's management disclose more segment information vis-à-vis the companies classified in other sectors. It is unknown why more segment data are disclosed if a company is classified in the construction sector. It can be conjectured that the greater extent of segment disclosers is a consequence of greater competition between companies, the separation of operational areas, etc., vis-à-vis the companies classified in another sector.

Further research investigates whether the individual segment disclosures influence the disclosure of partial segment information, whether there is a disclosure pattern that is reflected in the behaviour of company management in disclosing segment information, and whether the companies can be classified into clusters based on their disclosure pattern. The DIV method is used. ${ }^{22}$ The number of clusters must be determined in advance (Chavent et al. 2006), and factors such as the sample size of the collected data and the requirements of the statistical methods are taken into consideration. Figure 1 shows the result of the division into three groups based on the collected sample data. ${ }^{23}$

22 The DIV method is possible with the assistance of the SODAS (Symbolic Official Data Analysing System) computer programme.

23 The number of clusters must be determined in advance, which is why there was a preliminary test of "division" into 2, 3, 4, and 5 clusters. The classification into groups is based on the segment disclosures, taking into consideration all thirteen mandatory disclosures in the SAS (presented in Table 1). Because the studied sample includes data for 41 unlisted companies that disclose information by segments and use the SAS and considering the requirements of the statistical tools when analysing data, the preliminarily determined adequate number of clusters is 3 , which is the number at which there would be at least 13 companies in each cluster with an even division of groups into clusters. 
Figure 1: Clustering tree

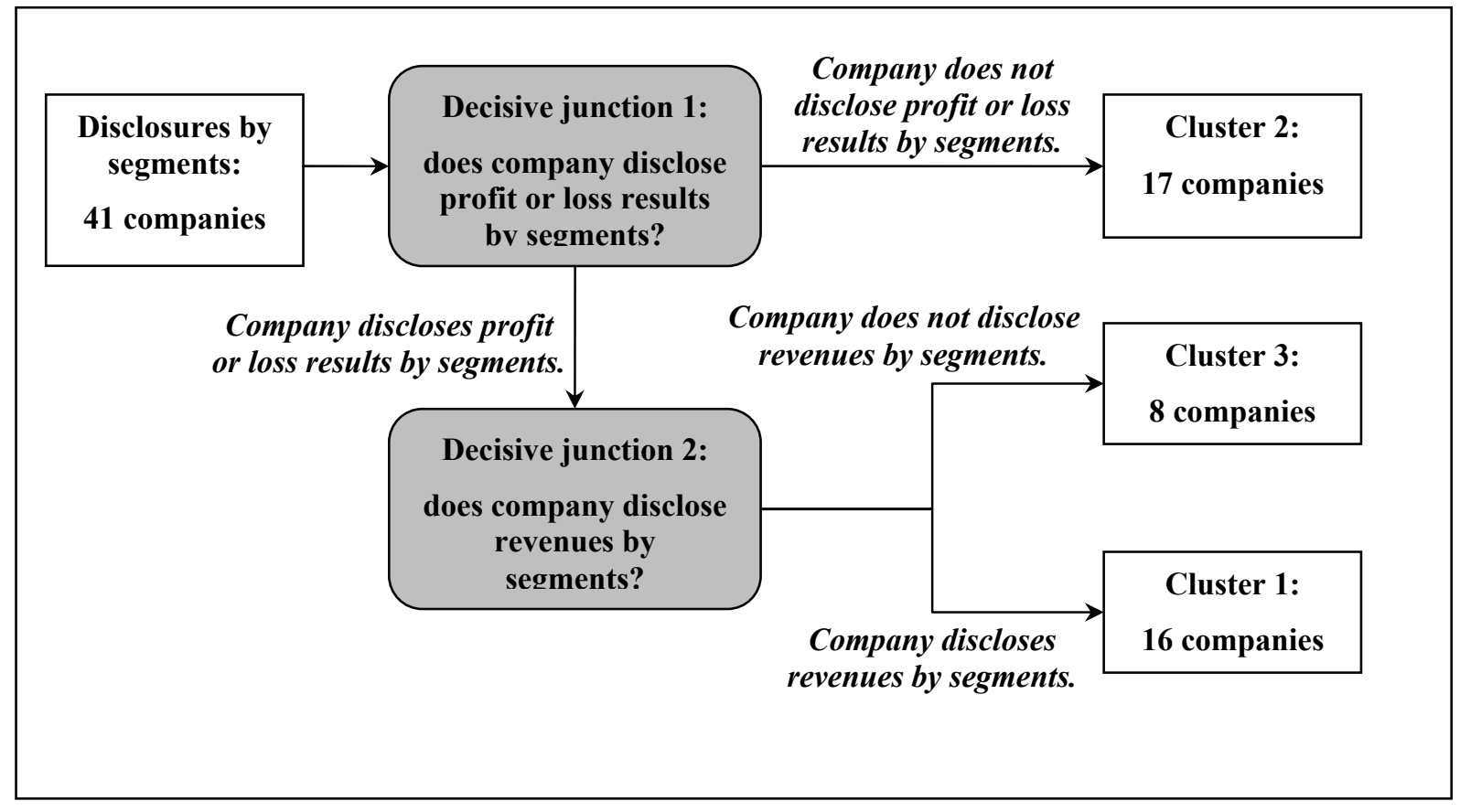

The classification of companies into clusters in accordance with the disclosure of information by segments shows that the two important factors when classifying the companies into three groups are whether the company disclosed its segment profit and loss and whether the company disclosed its segment revenue. The disclosure of profit and loss results by segment thus generally determines the company's disclosure pattern in regard to the behaviour of the company's management when disclosing segment information.

Table 3 shows the descriptive statistics of the companies' disclosed information by segments in accordance with the classification of the companies into three clusters using the DIV method. The data on the share of companies within the clusters that reveal information by segments are as follows: $84.25 \%$ of all companies classified in cluster $1,94.12 \%$ of all companies classified in cluster 2 , and $37.50 \%$ of all companies classified in cluster 3 disclose the composition of their business segments. The average (unweighted) disclosure index for all companies classified into clusters shows that the companies classified in cluster 2 disclose the most (the greatest extent of) information by segments (the average disclosure index of the cluster is 0.5745 ). The companies classified in cluster 1 disclose less information (0.2791), and the companies classified in cluster 3 disclose the least information (0.1155). This result from the DIV method shows that the clusters have different levels for disclosure of information by segments. The latter is also shown by the result of the chi-square test for disclosures by segments, given that the extent of the disclosures - in the majority of the disclosures by segment - is statistically significantly different (see the value of the chi-square test results in Table 3) between the clusters. The disclosure of revenue by segments, which is the second decisive junction when classifying 
companies into clusters, is therefore statistically significant considering the results of the chi-square test (at the $1 \%$ confidence level). It is unclear why the disclosure of profit or loss results by segment, which is the first decisive junction, is not statistically significant according to the results of the chi-square test. Considering that not all results are statistically significant (when discussing the disclosure of assets and liabilities by segments, the disclosure of profit or loss results by segment and the disclosure of segment accounting policies), it holds true that the classification into clusters is not completely without "intersections" among the clusters.

Table 3: Descriptive statistics of the disaggregated information disclosures in accordance with the classification of companies in three clusters

\begin{tabular}{|c|c|c|c|c|c|c|}
\hline & Disclosure of ... & $\begin{array}{l}\text { Share of c } \\
\text { informati }\end{array}$ & $\begin{array}{l}\text { mpanies d } \\
\text { n within es }\end{array}$ & $\begin{array}{l}\text { sclosing } \\
\text { ch cluster }\end{array}$ & $\begin{array}{l}p-v^{2} \\
\left(\chi^{2}-\right.\end{array}$ & \\
\hline & & Cluster 1 & Cluster 2 & Cluster 3 & & \\
\hline 1 & ... business segment composition & 84.25 & 94.12 & 37.50 & .000 & $* * *$ \\
\hline 2 & $\begin{array}{l}\text {... geographical segment } \\
\text { composition }\end{array}$ & 43.75 & 23.53 & 25.00 & .019 & $* *$ \\
\hline 3 & $\begin{array}{l}\text {... profit or loss results by } \\
\text { segment }\end{array}$ & .00 & 100.00 & .00 & .274 & \\
\hline 4 & ... revenues by segment & 100.00 & 100.00 & .00 & .000 & $* * *$ \\
\hline 5 & $\begin{array}{l}\text {... revenues by segment in table } \\
\text { form }\end{array}$ & 100.00 & 100.00 & .00 & .000 & $* * *$ \\
\hline 6 & $\ldots$ assets by segment & 18.75 & 82.35 & 25.00 & .639 & \\
\hline 7 & ... liabilities by segment & 12.50 & 82.35 & 12.50 & .274 & \\
\hline 8 & $\begin{array}{l}\text {... method for determining costs } \\
\text { by segment }\end{array}$ & .00 & 35.29 & 12.50 & .000 & $* * *$ \\
\hline 9 & $\begin{array}{l}\text {... allocation measures of } \\
\text { revenues and expenses by } \\
\text { segment }\end{array}$ & .00 & 47.06 & .00 & .000 & $* * *$ \\
\hline 10 & $\begin{array}{l}\text {... method of pricing intra- } \\
\text { segment transfers }\end{array}$ & .00 & .00 & .00 & .000 & $* * *$ \\
\hline 11 & $\begin{array}{l}\text {... adopted accounting policies for } \\
\text { segment reporting }\end{array}$ & 6.25 & 76.47 & 25.00 & .160 & \\
\hline 12 & ... segment reconciliations & .00 & .00 & 12.50 & .000 & $* * *$ \\
\hline 13 & ... segment profitability ratios & .00 & 5.88 & .00 & .000 & $* * *$ \\
\hline & All companies (41) & 16 & 17 & 8 & & \\
\hline & $\begin{array}{l}\text { Average disclosure index per } \\
\text { cluster }\end{array}$ & .2791 & .5745 & .1155 & & \\
\hline
\end{tabular}

Notes: $*$ Statistically significant at $0.10 . * *$ Statistically significant at $0.05 . * * *$ Statistically significant at 0.01 . 
Considering the individual disclosures by segments, the classification into three clusters indicates three different disclosure patterns for companies in terms of the behaviour of the company's management when disclosing segment information. Even the results of the Kruskal-Wallis test (as a non-parametric test) on the collected data indicate there are three different disclosure patterns (see Table 4). The results for the dependent variable show that there are statistically significant differences among the clusters (at the $1 \%$ confidence level). The companies classified in cluster 2 disclose the most (the largest extent of) segment information. The disclosure of information about profit or loss results by segments, which according to the result of the DIV method is the first decisive junction, influences the disclosure pattern of the company. In other words, company management that discloses information about profit or loss results by segment will be classified into cluster 2 and will disclose more segment information than the companies in the other (remaining) clusters.

However, according to the results of the Kruskal-Wallis test with other factors, it is not possible to claim that companies that are classified into cluster 2 disclose more (a larger extent of) information compared to the companies classified into other clusters. The differences between the clusters show that none of the considered factors influences the classification of the company into one of the clusters, and, consequently, these differences do not influence the company's disclosures related to the segment information. The only factor that slightly exceeds the statistically significant $10 \%$ confidence level is the level of the debt financing of companies, which indicates that the companies with lower rates of financial leverage disclose more segment information. This finding could imply that the segment disclosures can be used to decrease possible agency costs and reduce information asymmetries.

Table 4: Kruskal-Wallis test of difference between clusters

\begin{tabular}{|c|c|c|c|c|c|c|}
\hline & \multicolumn{3}{|c|}{$\begin{array}{l}\text { Rank average } \\
\text { (Number of companies: 41) }\end{array}$} & \multirow[t]{2}{*}{$\chi^{2}$-test } & \multirow{2}{*}{\multicolumn{2}{|c|}{$\begin{array}{l}\text { Statistical } \\
\text { significance }\end{array}$}} \\
\hline & $\begin{array}{l}\text { Cluster } 1 \\
(\mathrm{~N}=16)\end{array}$ & $\begin{array}{l}\text { Cluster } 2 \\
(\mathrm{~N}=17)\end{array}$ & $\begin{array}{c}\text { Cluster } 3 \\
(\mathrm{~N}=8)\end{array}$ & & & \\
\hline $\begin{array}{l}\text { Unweighted disclosure } \\
\text { index }\end{array}$ & 15.28 & 32.32 & 8.38 & 28.149 & .000 & $* * *$ \\
\hline Size_In_Revenues & 22.69 & 21.76 & 16.00 & 1.781 & .411 & \\
\hline Financial leverage & 25.63 & 17.82 & 18.50 & 3.929 & .140 & \\
\hline Profitability & 22.56 & 17.76 & 24.75 & 2.296 & .317 & \\
\hline Growth_rate & 19.25 & 24.35 & 17.38 & 2.406 & .300 & \\
\hline
\end{tabular}

Notes: * Statistically significant at $0.10 . * *$ Statistically significant at $0.05{ }^{* * *}$ Statistically significant at 0.01 . 
Considering the results of the regression analysis, the company size is not a (statistically) significant factor that influences the extent of the disclosed information by segments. The theoretical generally (a priori) accepted "belief" that the larger the company is, the greater the extent of the company's disclosed segment information, does not hold true. Compared to other studies that show a significance for the company size factor, ${ }^{24}$ the non-significance of the company size factor is unusual (unexpected). One possible reason for the non-significance of the company size factor could be that the present research focuses on Slovenian companies, which are unlisted companies, whereas the subjects of the earlier studies are generally listed companies. Another possible reason is that in the earlier studies, the research focused on companies that are a several times larger (for example, ten times, a hundred times or even more) than the companies studied in the present research. ${ }^{25}$ The results of the regression analysis show that company size is not necessarily (statistically) significant for the unlisted companies. ${ }^{26}$ The (statistical) non-significance of the company size factor means that the agency costs are not higher for larger companies. Larger companies do not disclose more segment information to decrease higher agency costs. Furthermore, proprietary costs are not lower for larger companies. Larger companies do not disclose more segment information because of lower proprietary costs. Nevertheless, the results of the disclosure pattern analysis show that the company size does not affect the type of disclosed segment information. The company size, therefore, does not affect the behaviour of the company management regarding the disclosure of individual segment information.

The results of the disclosure pattern analysis and the regression analysis show that the financial leverage of the company is not a (statistically) significant factor that would influence the extent of disclosed information by segments or the type of disclosed information by segments. The "belief" generally accepted in advance (a priori), based on a number of different theories (for example, the agency theory), that the more a company is in debt, the greater the extent of their disclosed segment information, does not hold true. Compared to other studies that show the statistical non-significance of the company's financial leverage, ${ }^{27}$ the non-significance of the financial leverage is at least partly unusual (unexpected). One or many of the possible reasons for the statistical nonsignificance of the company size factor could also cause the statistical non-

24 See discussion infra Chapter 3.

25 Compare, for example, with studies such as Ettredge et al. (2002), Prencipe (2004), Botosan and Stanford (2005), Berger and Hann (2007), etc.

26 It is worth adding that a possible reason can also be that in the majority of previous studies, the subjects of the study were companies that operate and have their headquarters in the United States of America. Compare this study, for example, with studies such as Herrmann and Thomas (2000), Botosan and Stanford (2005), Berger and Hann (2007), etc.

27 See discussion infra Chapter 3. 
significance of financial leverage. Furthermore, due to a small economic environment (such as the "limited" Slovenian economic environment when compared to the potential extent of the world economic environment), another possible reason could also be that the companies do not disclose information by segments in the annual reports because they disclose information by segments privately (non-publicly in an agency relationship between two parties). Considering the results of the disclosure pattern, even the type of individual disclosures is not influenced by the company's financial leverage.

The profitability factor, according to the disclosure pattern analysis and the regression analysis, is not a (statistically) significant factor that would influence the extent of the disclosed information by segments or the type of disclosed information by segments. The general expectation, related to the agency theory and the signalling theory about the positive relationship and related to proprietary costs theory about the negative relationship, does not hold true. The proprietary costs theory indicates that the more profitable companies do not disclose a greater range of segment information compared to the less profitable companies. Finding that the profitability factor is not necessarily always a (statistically) significant factor is in accordance with the findings of some previous studies. ${ }^{28}$ One possible reason for the (statistical) non-significance of profitability could be that profitability can be an investment quality indicator (Prencipe 2004: 334) and also an indicator that shows the company's belowaverage or above-average success (profitability) in relation to its competitors. Additionally, it can be said that the disclosure of information can have harmful consequences for the company, leading management, irrespective of the achieved profitability, to disclose less segment information. These opposite consequences indicate that the relationship between profitability and the extent of the disclosed information by segments cannot be determined with certainty. Even the results of the disclosure pattern analysis show that the type of disclosed information is not influenced by the profitability.

The results of the disclosure pattern analysis and the regression analysis show that the company's growth rate is not a (statistically) significant factor that would influence the extent of disclosed information by segments or the type of disclosed information by segments. The hypothesis that the higher the company's growth rate is, the lesser the extent of the disclosed segment information is not valid considering the results of this research. As already stated by Prencipe (2004), one possible reason that this hypothesis is not valid can be found in the fact that the growth (measured by the growth rate of all of the company's assets) can be an indicator of investment quality. Thus, it can hold true that the companies with high growth have higher proprietary costs, due to the disclosure of segment information, compared to the companies without

28 Compare this research, for example, with the research of Lang and Lundholm (1993), Wallace et al. (1994), Hossain and Hammami (2009), etc. 
growth. However, the motivation for these high-growth companies to disclose segment information is greater because of, for example, the desire to minimise future risk connected to a possible negative public reputation ("publicity"), adverse market selection and so on. These consequences could have had at least a partial influence on the company's proprietary costs.

In regard to the dummy variables that show the basic (primary) industry sector of the company, the results of the regression analysis show that it is (statistically) significant if the company is classified in the construction sector. This finding indicates that for the companies classified in the construction sector in terms of their primary activity, the management will disclose more segment information compared to those companies classified in any other sector. The cause for more segment disclosures for these companies is unknown. It can be conjectured that the greater extent of segment disclosers are a consequence of a greater number of competitors on the market, the existence of divisible areas operations, etc., vis-à-vis the companies classified in any other sector.

Nevertheless, it is unexpected (unusual) that such a high number of factors, with the exception of one, are (statistically) non-significant. The factors (company size, financial leverage and profitability) were found to be significant in most of the earlier studies in the field of segment reporting issues and/or other financial reporting issues. As already stated, one possible reason that these factors are non-significant is that this research focused on unlisted companies, companies that are - in relation to size - several times (for example ten times, a hundred times or even more) smaller than the companies studied in previous studies and/or it focuses on companies that operate and have their headquarters in the territory of Slovenia and not in one of the larger economies (such as the United States of America).

\section{Conclusions}

The aim of the research was to determine the behaviour ("business practises") of the management of large Slovenian unlisted companies in regard to disclosing information by segments in their annual reports and whether factors as company size, financial leverage, profitability, company growth and company industry sector influence the decision of the companies' management to disclose segment information in the annual reports. The decision about the disclosure of segment information (which is usually characterised as proprietary information) is in the hands of the company's management, and this decision regarding the (accounting) policy and the disclosure of information is (generally) strategic. The results of the regression analysis, where the (unweighted) disclosure index represents the dependent variable as the measure for extent of the disclosure of segment information, show that for Slovenian unlisted companies that use the SAS and disclose information by segments, none of the expected factors (company size, financial leverage, profitability or company growth rate) is 
identified as a significant factor that would influence the decision of the company's management about the extent of the disclosed segment information in the company's annual report. Considering the studied sample of companies, the only factor that presents itself as (statistically) significant is whether the company operates in the construction industry. The results show that companies classified in the construction sector will disclose more segment information compared to the companies classified in any other sector. The research results imply that neither agency costs nor proprietary costs are important when management decides the extent of the segment information to disclose in the annual reports of large Slovenian unlisted companies. Considering the research design, other possible reasons for the management decision of these companies about the disclosure of information by segments cannot be determined.

The study of management behaviour ("business practises") in Slovenian unlisted companies in regard to disclosing information by segments in the companies' annual reports shows that two facts are important in this disclosure - whether the company has disclosed its profit or loss results by segment and whether the company has disclosed its revenues by segment. Three different "business practises" (clusters) can be identified among the management of these Slovenian companies based on their behaviour when disclosing individual types of information; however, regarding distinguishing these "business practices", no factor is (statistically) significant.

The present research represents the first study of the behaviour of company management with regard to the disclosure of (accounting) segment information on a sample of unlisted companies. However, it must be stated that the results of the research cannot be generalised to the companies that do not use the SAS. ${ }^{29}$ One of the limitations of our study that could influence our research results is the unexpected finding that over three quarters of the large Slovenian unlisted companies do not disclose the mandatory segment information. The sample of the remaining quarter of the large Slovenian unlisted companies that disclose segment information cannot be considered to be a large sample. Therefore, these sample characteristics increase the risk that the study results are inconclusive. Nevertheless, the reasons that over three quarters of Slovenian companies do not disclose information by segments in accordance with the generally accepted accounting principles can vary (it could be a consequence of a strategic decision by the company's management not to disclose information) and are therefore hard, or even impossible, to determine. This situation - in which over three quarters of the companies do not disclose segment information despite the unambiguous and well-known requirements of the generally accepted accounting principles in force about this disclosure - indicates a problem in the currently established "business practice" of these companies' management (and

29 A generalisation of the research results is not recommended without a previous study. 
thus a problem of management behaviour). Last, but not least, this situation indicates a problem in the financial reporting framework currently in force in Slovenia. One possible course for further research could be a further study of this problem, particularly as to whether these problems are related to lack of control, the non-existence of sanctions or other possible problems related to the "reward" for concealing information. Another question that arises is whether the fact that there is no suitable reward for the disclosure of information (or detected benefits by companies) creates a problem.

\section{References}

Ahmed, K./Courtis, J. K. (1999): Associations between Corporate Characteristics and Disclosure Levels in Annual Reports: A Meta-analysis, in: The British Accounting Review, 31, 1, 35-61.

Barako, D. G. (2007): Determinants of Voluntary Disclosures in Kenyan Companies Annual Reports, in: African Journal of Business Management, 1, 5, 113-128.

Behn, B. K./Nichols, N. B./Street, D. L. (2002): The Predictive Ability of Geographic Segment Disclosures by U.S. Companies: SFAS No. 131 vs. SFAS No. 14, in: Journal of International Accounting Research, 1, 1, 31-44.

Berger, P. G./Hann, R. N. (2003): The Impact of SFAS No. 131 on Information and Monitoring, in: Journal of Accounting Research, 41, 2, 163-223.

Berger, P. G./Hann, R. N. (2007): Segment Profitability and the Proprietary and Agency Costs of Disclosure, in: The Accounting Review, 82, 4, 869-906.

Birt, J./Kend, M./Xian, H. (2007): Changes in Segment Reporting in the Australian Banking Industry, in: Australian Accounting Review, 17, 3, 61-67.

Botosan, C. A. (1997): Disclosure Level and the Cost of Equity Capital, in: The Accounting Review, 72, 3, 323-349.

Botosan, C. A./Stanford, M. (2005): Managers' Motives to Withhold Segment Disclosures and the Effect of SFAS No. 131 on Analysts' Information Environment, in: The Accounting Review, 80, 3, 751-771.

Botosan, C. A. (2000): Evidence that Greater Disclosure Lowers Cost of Equity Capital, in: Journal of Applied Corporate Finance, 12, 4, 60-69.

Čater, T./Pučko, D. (2010): Factors of Effective Strategy Implementation: Empirical Evidence from Slovenian Business Practice, in: Journal for East European Management Studies, $15,3,207-236$.

Chavent, M. (1998): A Monothetic Clustering Method, in: Pattern Recognition Letters, 19, 11, 989-996.

Chavent, M./Ding, Y./Fu, L./Stolowy, H./Wang, H. (2006): Disclosure and Determinants Studies: An Extension Using the Divisive Clusering Method (DIV), in: European Accounting Review, 15, 2, 181-218.

Chow, C. W./Wong-Boren, A. (1987): Voluntary Financial Disclosure by Mexican Corporations, in: The Accounting Review, 62, 3, 533-541. 
Christie, A. A./Zimmerman, J. L. (1994): Efficient and Opportunistic Choices of Accounting Procedures: Corporate Control Contests, in: The Accounting Review, 69, 4, 539-566.

Deppe, L./Omer. S. C. (2000): Disclosing Disaggregated Information, in: Journal of Accountancy, 190, 3, 47-54.

Doupnik, T. S./Seese, L. P. (2001): Geographic Area Disclosures under SFAS 131: Materiality and Fineness, in: Journal of International Accounting, Auditing \& Taxation, 10, 2, 117-138.

Ettredge, M. L./Kwon, S. Y./Smith, D. B./Stone, M. S. (2006): The Effect of SFAS No. 131 on the Cross-segment Variability of Profits Reported by Multiple Segment Firms, in: Review of Accounting Studies, 11, 1, 91-117.

Ettredge, M. L./Kwon, S. Y./Smith, D. B./Zarowin, P. A. (2005): The Impact of SFAS No. 131 Business Segment Data on the Market's Ability to Anticipate Future Earnings, in: The Accounting Review, 80, 3, 773-804.

Ettredge, M./Kwon, S. K./Smith D. B. (2000): The Effect of SFAS No. 131. On Numbers of Reported Business Segments, available at: http://ssrn.com/abstract=208549 [15. 09. 2012].

Ettredge, M./Kwon, S. Y./Smith, D. (2002): Competitive Harm and Companies' Position on SFAS No. 131, in: Journal of Accounting, Auditing \& Finance, 17, 2, 93-109.

Francis, J. R./Khurana, I. K./Pereira, R. (2005): Disclosure Incentives and the Effects on the Cost of Capital around the World, in: The Accounting Review, 80, 4, 1115-1162.

Harris, M. S. (1998): The Association between Competition and Managers' Business Segment Reporting Decisions, in: Journal of Accounting Research, 36, 1, 111-128.

Hayes, R. M./Lundholm, R. (1996): Segment Reporting to the Capital Market in the Presence of a Competitor, in: Journal of Accounting Research, 34, 2, 261-279.

Healy, P. M./Palepu, K. G. (2001): Information Asymmetry, Corporate Disclosure, and the Capital Markets: A Review of the Empirical Disclosure Literature, in: Journal of Accounting and Economics, 31, 1-3, 405-440.

Herrmann, D./Thomas, W. B. (1996): Segment Reporting in the European Union: Analysing the Effects of Country, Size, Industry, and Exchange Listing, in: Journal of International Accounting and Taxation, 5, 1, 1-20.

Herrmann, D./Thomas, W. B. (2000): An Analysis of Segment Disclosures under SFAS No. 131 and SFAS No. 14, in: Accounting Horizons, 14, 3, 287-302.

Hossain, M./Hammami, H. (2009): Voluntary Disclosure in the Annual Reports of an Emerging Country: The Case of Qatar, in: Advances in Accounting, incorporating Advances in International Accounting, 25, 2, 255-265.

Jensen, M. C./Meckling, W. H. (1976): Theory of the Firm: Managerial Behavior, Agency Costs and Ownership Structure, in: Journal of Financial Economics, 3, 4, 305-360.

Keene, O. N. (1995): The Log Transformation is Special, in: Statistics in Medicine, 14, 8, 811-819.

Lang, M./Lundholm, R. (1993): Cross-sectional Determinants of Analyst Ratings of Corporate Disclosures, in: Journal of Accounting Research, 31, 2, 246-271. 
Leuz, C. (2004): Proprietary versus Non-Proprietary Disclosures: Evidence from Germany, in: Leuz, C./Pfaff, D./Hopwood, A. (ed.): The Economics and Politics of Accounting: internatioanl Perspectives on Research Trends, Policy and Practice, Oxford: Oxford University Press, 164-197.

Maines, L. A./McDaniel, L. S./Harris, M. S. (1997): Implications of Proposed Segment Reporting Standards for Financial Analysts' Investment Judgments, in: Journal of Accounting Research, 35, Supplement, 1-24.

McKinnon, J. L./Dalimunthe, L. (1993): Voluntary Disclosure of Segment Information by Australian Diversified Companies, in: Accounting and Finance, 33, 1, 33-50.

Meek, G. K./Roberts, C. B./Gray, S. J. (1995): Factors Influencing voluntary Annual Report Disclosures by U.S., U.K. and Continental European Multinational Corporations, in: Journal of International Business Studies, 26, 3, 555-572.

Mian, S. L./Smith, C. W. (1990): Incentives for Unconsolidated Financial Reporting, in: Journal of Accounting and Economics, 12, 1-3, 147-171.

Mihelič, K. K./Lipičnik, B. (2010): Corporate Managers and Their Potential Younger Succesors: An Examination of Their Values, in: Journal for East European Management Studies, 15, 4, 288-311.

Mitchell, J. D./Chia, C. W. L./Loh, A. S. (1995): Voluntary Disclosure of Segment Information: Further Australian Evidence, in: Accounting \& Finance, 37, 4, 1-16.

Mühlbacher, J./Nettekoven, M./Kovac, J. (2011): Competency Management in Slovenia: Paradoxes between Development Trends and Drivers of Change, in: Journal for East European Management Studies, 16, 1, 75-90.

O'Brien, R. M. (2007): A Caution Regarding Rules of Thumb for Variance Inflation Factors, in: Quality \& Quantity, 41, 5, 673-690.

Paul, J. W./Largay III, J. A. (2005): Does the "Management Approach" Contribute to Segment Reporting Transparency?, in: Business Horizons, 48, 4, 303-310.

Piotroski, J. D. (2003): Discussion of The Impact of SFAS No. 131 on Information and Monitoring, in: Journal of Accounting Research, 41, 2, 225-234.

Prather-Kinsey, J./Meek, G. K. (2004): The Effect of Revised IAS 14 on Segment Reporting by IAS Companies, in: European Accounting Review, 13, 2, 213-234.

Prencipe, A. (2004): Proprietary Costs and Determinants of Voluntary Segment Disclosure: Evidence from Italian Listed Companies, in: European Accounting Review, 13, 2, 319-340.

Sanders, J./Alexander, S./Clark, S. (1999): New Segment Reporting. Is It Working?, in: Strategic Finance, 81, 6, 35-38.

Spence, M. (1973): Job Market Signalling, in: Quartely Journal of Economics, 87, 3, 335374.

Street, D. L./Nichols, N. B. (2002): LOB and Geographic Segment Disclosures: An Analysis of the Impact of IAS 14 Revisited, in: Journal of International Accounting, Auditing and Taxation, 11, 2, 91-113.

Street, D. L./Nichols, N. B./Gray, S. J. (2000): Segment Disclosures under SFAS No. 131: Has Business Segment Reposting Improves?, in: Accounting Horizons, 14, 3, 259285. 
Troberg, P./Kinnunen, J./Seppänen, J. H. (2010): What Drives Cross-Segment Diversity in Returns and Risks? Evidence from Japanese and U.S. Firms, in: The International Journal of Accounting, 45, 1, 44-76.

Urquiza, F. B./Navarro, M. C. A./Trombetta, M. (2010): Disclosure Indices Design: Does it Make a Difference?, in: Revista de Contabilidad, 12, 2, 253-278.

Wallace, R. S. O./Naser, K. (1995): Firm-Specific Determinants of the Comprehensiveness of Mandatory Disclosure in the Corporate Annual Reports of Firms Listed on the Stock Exchange of Hong Kong, in: Journal of Accounting and Public Policy, 14, 4, 311-368.

Wallace, R. S. O./Naser, K./Mora, A. (1994): The Relationship between the Comprehensiveness of Corporate Annual Reports and Firm Specific Characteristics in Spain, in: Accounting and Business Research, 25, 97, 41-53.

Wooldridge, J. (2002): Introductory Econometrics: A Modern Approach. Second Edition. London: South-Western College Pub. 